\title{
KELIMPAHAN CHRYSOPHYTA PADA MEDIA BUDIDAYA IKAN NILA YANG DIBERI PAKAN FERMENTASI DENGAN PENAMBAHAN TEPUNG KULIT UBI KAYU DAN PROBIOTIK
}

\author{
REtno AmbarWATI, ENDANG Widyastuti, DWi Sunu WidYARTini \\ Fakultas Biologi, Universitas Jenderal Soedirman, Jalan dr. Suparno 63 Purwokerto 53122
}

\begin{abstract}
A B S T R A C T
Chrysophyta is also known as golden-yellow algae because of the yellow dominant pigment of carotene and xanthophyll. This study aimed to determine species richness and abundance of Chrysophyta in the Tilapia culture media which was fed with the addition of cassava peel flour and probiotic. The method applied in this study was the experimental method with 4 treatments, i.e.: the use of fermented feed with the addition of cassava peel flour $(0 \%, 25 \%, 50 \%$, and $75 \%)$ and probiotic in Tilapia culture media. Each treatment was replicated 4 times. Sampling was carried out 6 times at intervals of 2 weeks. The observed parameters were the main parameters, i.e.: the number of Chrysophyta species and individuals; and supporting parameters, i.e.: water temperature, pH, TDS, TSS, NO3, NO2, BOD5, DO, and total of phosphate. Species richness and abundance of Chrysophyta data were analyzed using cluster analysis based on Bray-Curtis similarity coefficient. The analysis continued with Similarity Percentages (SIMPER) analysis to determine the contribution of species to the similarity index in each group or to dissimilarity index amongst groups. The results showed that the species richness found in the Tilapia media culture which was fed with the addition of cassava peel flour and probiotic consist of 20 species belonging to a class namely Bacillariophyceae. Abundance of Chrysophyta obtained was ranged from 5.160-13.292 individuals/liter. The cluster analysis showed that Chrysophyta amongst treatments have a quite high similarity level $(>50 \%)$ was ranged between $65.56 \%-83.99 \%$. Contributions of species which contribute the highest similarity index were Diatoma vulgare (49.80\%), Navicula brachysira (70.50\%) and Navicula platystoma (82\%).
\end{abstract}

KEY WORDS: Abundance of Chrysophyta, cassava peel flour, probiotic, culture of Tilapia

Penulis korespondensi: RETNO AMBARWATI | email: babank_cute@yahoo.co.id

\section{PENDAHULUAN}

Chrysophyta digolongkan ke dalam 3 kelas, yaitu Bacillariophyceae, Xantophyceae, dan Chrysophyceae. Chrysophyta mempunyai ciri-ciri antara lain dinding sel diperkuat dengan bahan silikat (Dodds, 2002), berflagel yang tidak sama panjangnya dan tidak sama bentuknya (Heterokontae) (Sze, 1993). Sel terdiri dari dua bagian, tutup (epiteka) dan wadah (hipoteka). Pigmen terdiri dari karotin dan xanthofil yang berwarna kuning (Sachlan, 1982).

Kelimpahan menurut Odum (1993) yaitu jumlah individu per satuan volume. Kelimpahan jenis di suatu perairan dipengaruhi oleh beberapa parameter lingkungan dan karakteristik fisiologisnya. Chrysophyta pada media budidaya nutriennya dapat dipengaruhi oleh sisa pakan dan feses yang dikeluarkan oleh ikan. Dalam budidaya ikan pemberian pakan tambahan sangat diperlukan untuk mempercepat pertumbuhan ikan (Muhiddin et al., 2001). Untuk memperoleh hasil budidaya ikan yang baik dan menguntungkan perlu pakan yang baik dengan kandungan nutrisi yang dapat memenuhi kebutuhan metabolisme ikan.

Salah satu alternatif pakan dengan bahan baku murah adalah dengan penggunaan kulit ubi kayu. Kulit ubi kayu merupakan limbah dari pabrik tapioka yang memungkinkan sebagai bahan baku alternatif pembuatan pakan ikan. Kulit ubi kayu masih mengandung bahan-bahan organik seperti karbohidrat, protein, lemak, dan mineral (Rukmana, 1997). Kualitas pakan juga dapat ditingkatkan dengan pemberian probiotik $\mathrm{MEP}^{+}$. Probiotik yang berisi mikroba pengurai bila dimasukkan ke dalam pakan, dapat meningkatkan kecernaan pakan dengan proses penguraian yang dilakukan oleh mikroba tersebut (Tango, et al., 2007 dalam Widyastuti, et al., 2010).

Adanya probiotik $\mathrm{MEP}^{+}$dan pakan fermentasi dengan penambahan tepung kulit ubi kayu pada konsentrasi berbeda di media budidaya ikan dapat menyebabkan keadaan lingkungan yang tidak sama sehubungan dengan sisa pakan dan feses yang dikeluarkan, sehingga pertumbuhan Chrysophyta berbeda. Probiotik akan mendekomposer feses dan pakan yang terbuang.

Tujuan dari penelitian adalah

1. Mengetahui kekayaan jenis Chrysophyta pada media budidaya ikan nila yang diberi pakan fermentasi dengan penambahan tepung kulit ubi kayu dan probiotik.

2. Mengetahui kelimpahan Chrysophyta pada media budidaya ikan nila yang diberi pakan fermentasi dengan penambahan tepung kulit ubi kayu dan probiotik.

Penelitian ini diharapkan dapat bermanfaat untuk dasar dalam pengembangan budidaya Chrysophyta.

\section{ME T O D E}

Objek yang digunakan dalam penelitian adalah sampel Chrysophyta. Penelitian ini menggunakan metode eksperimen pada budidaya ikan nila dengan empat perlakuan yaitu: perlakuan A (pemberian pakan fermentasi dengan penambahan probiotik $\mathrm{MEP}^{+}$dan tanpa ditambahkan tepung kulit ubi kayu), perlakuan B (pemberian pakan fermentasi yang ditambahkan tepung kulit ubi kayu $25 \%$ dan probiotik MEP+), perlakuan C (pemberian pakan fermentasi yang ditambahkan tepung 
kulit ubi kayu $50 \%$ dan probiotik $\mathrm{MEP}^{+}$), perlakuan D (pemberian pakan fermentasi yang ditambahkan tepung kulit ubi kayu $75 \%$ dan probiotik $\mathrm{MEP}^{+}$).

Pengambilan sampel dilakukan sebanyak 6 kali ulangan dengan periode waktu pengambilan sampel 2 minggu. Parameter yang diukur meliputi parameter utama yaitu jumlah spesies dan jumlah individu Chrysophyta serta parameter fisik-kimiawi air sebagai parameter pendukung yaitu suhu, pH, Total Dispended Solid (TDS), Total Suspended Solid (TSS), Nitrat (NO3), Biological Oxygen Demand (BOD), total fosfat, oksigen (02) terlarut dan Nitrit (NO2).

Pengambilan sampel Chrysophyta dilakukan dengan mengambil $10 \mathrm{l}$ sampel air, kemudian disaring dengan cara menuangkan ke dalam plankton net no. 25. Air yang tertampung dalam botol plankton net dipindahkan ke dalam botol sampel plankton dan diberi formalin $40 \%$ hingga konsentrasinya menjadi 4\% kemudian diberi lugol 2-3 tetes (APHA, 1985). Formalin yang dibutuhkan dapat diperoleh dengan menggunakan rumus sebagai berikut :

$$
\mathrm{N}_{1} \times \mathrm{V}_{1}=\mathrm{N}_{2} \times \mathrm{V}_{2}
$$

Keterangan:

N1 = Konsentrasi formalin yang dikehendaki,

N2 = Konsentrasi formalin yang tersedia

V1 = Volume air yang terkonsentrasi dalam botol sampel,

V2 = Volume formalin yang dibutuhkan

Pengamatan Chrysophyta dilakukan menggunakan mikroskop dan diidentifikasi dengan menggunakan Shirota (1966), Wehr and Sheath (2003) dan Thompson (algae) Edmonson (1966) dengan perbesaran 400x. Penghitungan kelimpahan spesies menggunakan modifikasi Lackley Drop Microtransec Counting dengan perbesaran 100x (APHA, 1985). Hasil perhitungan dalam rumus sebagai berikut:

$$
\begin{gathered}
\sum \text { individu per liter }=\mathrm{N} \times \mathrm{F} \\
\mathrm{F}=\frac{\mathrm{Q} 1}{\mathrm{Q} 2} \times \frac{\mathrm{V} 1}{\mathrm{~V} 2} \times \frac{1}{\mathrm{P}} \times \frac{1}{\mathrm{~W}}
\end{gathered}
$$

Keterangan:

$\mathrm{F}=$ Jumlah plankton per liter

$\mathrm{N}$ = Jumlah plankton rata-rata yang ditemukan

$\mathrm{Q} 1$ = Luas gelas penutup 18x18 mm (324 mm²)

$\mathrm{Q} 2$ = Luas lapang pandang $\left(1,11279 \mathrm{~mm}^{2}\right)$

$\mathrm{V} 1$ = Volume air dalam botol penampung $(300 \mathrm{ml})$

$\mathrm{V} 2=$ Volume air dalam gelas penutup $(0,05 \mathrm{ml})$

$\mathrm{P}=$ jumlah lapang pandang yang diamati (25x)

$\mathrm{W}$ = volume air yang disaring (10 l)

Kekayaan jenis Chrysophyta dianalisis secara deskriptif dan kelimpahan Chrysophyta dianalisis menggunakan cluster yang didasarkan pada koefisien kesamaan Bray-Curtis. Rumus koefisien kesamaan (Bray and Curtis, 1957 dalam Whitton, 1975) sebagai berikut:

$$
\begin{gathered}
\mathrm{QS}=\frac{2 \mathrm{~W}}{\mathrm{~A}+\mathrm{B}} \times 100 \% \\
\mathrm{PV}=\hat{\mathrm{C}} \times \mathrm{F}
\end{gathered}
$$

Keterangan :

$\mathrm{F} \quad=$ Frekuensi terdapatnya setiap spesies dari seluruh contoh di setiap komunitas

QS = Koefisien kesamaan

A =Jumlah Prominance Value dari spesies yang terdapat pada komunitas A yang dibandingkan

B =Jumlah Prominance Value dari spesies yang terdapat pada komunitas B yang dibandingkan

W =Jumlah Prominance Value terkecil antara komunitas A dan B

$\mathrm{PV}=$ Prominance value

$\hat{\mathrm{C}}=$ Jumlah rata-rata individu dari satu spesies dari seluruh contoh di setiap komunitas
Struktur komunitas dikatakan sama apabila nilai koefisien kesamaan didapatkan $>50 \%$ (Kendeigh, 1974 dalam Makatipu, et al., 2010). Analisis dilanjutkan dengan analisis Similarity Persentages (SIMPER) dengan bantuan program komputer PRIMER-E v.5. SIMPER digunakan untuk mengidentifikasi tingkat kontribusi setiap jenis Chrysophyta pada nilai kesamaan dalam tiap kelompok maupun nilai ketidaksamaan antar kelompok

\section{HASIL DAN PEMBAHASAN}

Chrysophyta yang didapatkan selama penelitian di media budidaya ikan nila yang diberi pakan fermentasi dengan penambahan tepung kulit ubi kayu dan probiotik $\mathrm{MEP}^{+}$terdiri dari 20 spesies yang kesemuanya termasuk dalam klas Bacillariophyceae (Tabel 1). Chrysophyta didapatkan dalam penelitian ini karena Chrysophyta mempunyai sifat kosmopolit. Sachlan (1982) menyatakan bahwa divisio Chrysophyta mempunyai sifat yang kosmopolit dan banyak ditemukan di perairan tawar.

Kekayaan spesies Chrysophyta yang paling tinggi didapatkan pada perlakuan D (pakan fermentasi yang ditambahkan tepung kulit ubi kayu 75\%) dengan jumlah 13 spesies, diikuti perlakuan C (konsentrasi tepung kulit ubi kayu 50\%) dan perlakuan B (konsentrasi tepung kulit ubi kayu 25\%) dengan jumlah 11 spesies, kekayaan terrendah dengan jumlah 8 spesies pada perlakuan A (konsentrasi tepung kulit ubi kayu 0\%). Hasil ini menunjukkan bahwa perlakuan pakan fermentasi dengan penambahan tepung kulit ubi kayu memberikan kekayaan spesies yang lebih tinggi dibandingkan pakan fermentasi tanpa penambahan tepung kulit ubi kayu. Kelimpahan Chrysophyta yang didapatkan berkisar antara 5160 ind/l-13292 ind/l. Kelimpahan tertinggi terdapat pada perlakuan C sebesar 13.292 ind/l (29,22\%). Diikuti perlakuan D sebesar 11,663 ind/l (25,64\%), perlakuan B sebesar 6,126 ind/l $(13,47 \%)$ dan kelimpahan terrendah pada perlakuan A sebesar 5,160 ind/l (11,35\%). Spesies Chrysophyta yang paling melimpah selama penelitian adalah Diatoma vulgare 30,96\%, Navicula brachysira $25,83 \%$, Nitzschia vermicularis $11,04 \%$, Navicula Platystoma, 10,42\%, dan Cyclotella operculata 5,17\%.

Ada beberapa spesies dari Chrysophyta yang ditemukan pada semua perlakuan tetapi memiliki kelimpahan yang rendah yaitu Cocconeus plasentula (33-567 ind/l) dan Stauroneis parvulum (33-317 ind/l). Selain itu, juga ada beberapa spesies Chrysophyta yang hanya dijumpai pada satu perlakuan saja yaitu spesies Amphora commutate hanya ditemukan di perlakuan B, Pinnularia legumen hanya ditemukan di perlakuan D, Amphora ovalis dan Stauroneis closterium hanya ditemukan perlakuan C.

Kelimpahan Chrysophyta antar perlakuan dianalisis dengan menggunakan analisis cluster berdasarkan indeks kesamaan Bray Curtis yang ditunjukkan Gambar 1 berdasarkan hasil analisis cluster, maka kelimpahan antar perlakuan memiliki kesamaan cukup tinggi yaitu $>50 \%$ berkisar antara 65,58\%-79.80\%. 
Berdasarkan Gambar 1 hasil analisis kelimpahan Chrysophyta berdasarkan indeks kesamaan BrayCurtis dihasilkan 2 kelompok kesamaan yaitu kelompok C dan D serta kelompok A dan B. Kesamaan perlakuan C (pemberian pakan fermentasi yang ditambahkan tepung kulit ubi kayu 50 \% dan probiotik $\mathrm{MEP}^{+}$) dan perlakuan D (pakan fermentasi yang ditambahkan tepung kulit ubi kayu $75 \%$ dan probiotik $\mathrm{MEP}^{+}$) yaitu sebesar $79.80 \%$. Perlakuan A (pakan fermentasi tanpa ditambahkan tepung kulit ubi kayu dan probiotik $\mathrm{MEP}^{+}$) memiliki kesamaan dengan perlakuan B (pakan fermentasi yang ditambahkan tepung kulit ubi kayu $25 \%$ dan probiotik $\mathrm{MEP}^{+}$) yaitu sebesar $72,16 \%$.

Tabel 1. Kelimpahan Chrysophyta yang didapatkan pada di media budidaya ikan nila yang diberi pakan fermentasi dengan penambahan tepung kulit ubi kayu dan probiotik

\begin{tabular}{|c|c|c|c|c|c|c|c|}
\hline \multirow{2}{*}{ No. } & \multirow{2}{*}{ Spesies } & \multicolumn{4}{|c|}{ Individu/Liter } & \multirow{2}{*}{ Rata-rata } & \multirow{2}{*}{$\begin{array}{l}\text { KR } \\
\%\end{array}$} \\
\hline & & A & $\mathrm{B}$ & $\mathrm{C}$ & $\mathrm{D}$ & & \\
\hline 1 & Amphora commutate & 0 & 33 & 0 & 0 & 7 & 0.07 \\
\hline 2 & Amphora ovalis & 0 & 0 & 33 & 0 & 7 & 0.07 \\
\hline 3 & Cocconeus pediculus & 0 & 633 & 283 & 183 & 220 & 2.42 \\
\hline 4 & Cocconeus plasentula & 367 & 567 & 33 & 200 & 233 & 2.57 \\
\hline 5 & Cyclotella operculata & 67 & 733 & 283 & 617 & 470 & 5.17 \\
\hline 6 & Diatoma vulgare & 2183 & 2166 & 6583 & 2300 & 2813 & 30.96 \\
\hline 7 & Ephitemia argus & 0 & 0 & 50 & 33 & 17 & 0.18 \\
\hline 8 & Gomphonema lancelatum & 0 & 67 & 33 & 67 & 33 & 0.37 \\
\hline 9 & Mastogloia elliptica & 0 & 33 & 267 & 167 & 247 & 2.72 \\
\hline 10 & Melosira salina & 0 & 67 & 0 & 50 & 33 & 0.37 \\
\hline & Navicula brachysira & 1067 & 900 & 2200 & 3433 & 2347 & 25.83 \\
\hline 12 & Navicula insuta & 0 & 0 & 100 & 50 & 30 & 0.33 \\
\hline 13 & Navicula platysoma & 500 & 567 & 1233 & 2283 & 947 & 10.42 \\
\hline & Nitzschia vermicularis & 317 & 283 & 950 & 1067 & 1003 & 11.04 \\
\hline 15 & Pinnularia legumen & 0 & 0 & 0 & 133 & 33 & 0.37 \\
\hline 16 & Rhopaloidea gibba & 100 & 33 & 667 & 600 & 280 & 3.08 \\
\hline 17 & Stauroneis acutum & 167 & 0 & 233 & 167 & 113 & 1.25 \\
\hline 18 & Stauroneis closterium & 0 & 0 & 100 & 0 & 20 & 0.22 \\
\hline 19 & Stauroneis parvulum & 317 & 33 & 233 & 167 & 157 & 1.72 \\
\hline 20 & Synedra acus & 67 & 0 & 0 & 133 & 63 & 0.70 \\
\hline Juml & ah Spesies & 8 & 11 & 11 & 13 & & \\
\hline Juml & ah Kelimpahan (ind/l) & 5160 & 6126 & 13292 & 11663 & 9286 & 100 \\
\hline & KR \% & 11.35 & 13.47 & 29.22 & 25.64 & & \\
\hline
\end{tabular}

Tabel 2. Indeks kesamaan Bray-Curtis Kelimpahan Chrysophyta antar perlakuan

\begin{tabular}{ccccc}
\hline & $\mathrm{A}$ & $\mathrm{B}$ & $\mathrm{C}$ & $\mathrm{D}$ \\
\hline $\mathrm{A}$ & $*$ & $*$ & $*$ & $*$ \\
$\mathrm{~B}$ & 72.16 & $*$ & $*$ & $*$ \\
$\mathrm{C}$ & 63.53 & 62.21 & $*$ & $*$ \\
$\mathrm{D}$ & 67.64 & 68.95 & 79.80 & $*$ \\
\hline
\end{tabular}

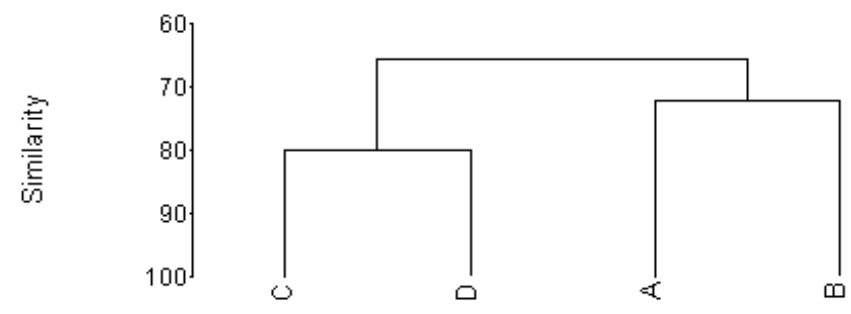

Gambar 1. Dendogram per bak budidaya kelimpahan Chrysophyta

Analisis lebih lanjut dengan analisis SIMPER yaitu untuk mengetahui kontribusi setiap jenis Chrysophyta pada nilai kesamaan dalam tiap kelompok maupun nilai ketidaksamaan antar kelompok. Dilakukan dengan mengelompokkan perlakuan A dan B menjadi kelompok I dan perlakuan C dan D menjadi kelompok II. Berdasarkan analisis SIMPER diperoleh spesies yang memberikan kontribusi tertinggi pada kelompok I yaitu Diatoma vulgare yang memberikan kontribusi 49,80\%, Navicula brachysira memberikan kontribusi 20,60\%, dan Navicula platystoma memberikan kontribusi 11,50\%.

Spesies yang memberikan kontribusi tertinggi pada kelompok II yaitu Diatoma vulgare memberikan kontribusi 27,38\%, Navicula brachysira memberikan kontribusi 26,19\%, dan Navicula platystoma memberikan kontribusi 14,68\%. Dengan demikian antara kelompok I dan kelompok II memiliki spesies yang memberikan kontribusi similaritas yang sama. spesies yang memberikan 
kontribusi similaritas yaitu Diatoma vulgare, Navicula brachysira, dan Navicula platystoma.

Nilai rata-rata disimilaritas antara kelompok I dan II adalah sebesar 46,53\% dengan Diatoma vulgare memberikan kontribusi 25,84\%, Navicula brachysira memberikan kontribusi 22,13\%, dan Navicula platystoma memberikan kontribusi $14,87 \%$. Spesies yang memberikan kontribusi nilai similaritas dan disimilaritas juga sama. Spesies yang memberikan kontribusi nilai similaritas dan disimilaritas yaitu Diatoma vulgare, Navicula brachysira, dan Navicula platystoma.

\begin{tabular}{|c|c|c|c|c|c|}
\hline \multicolumn{6}{|c|}{ Kelompok I average similarity: 77.20} \\
\hline Spesies & Av.Abund & Av.Sim & & rib. $\%$ & Cum. \% \\
\hline Diatoma vulgare & 2174.50 & 38.45 & & 49.80 & 49.80 \\
\hline Navicula brachysira & 983.50 & 15.98 & & 20.69 & 70.50 \\
\hline Navicula platystoma & 533.50 & 8.88 & & 11.50 & 82.00 \\
\hline \multicolumn{6}{|c|}{ Kelompok II average similarity: $67.38 \%$} \\
\hline Spesies & Av.Abund & Av.Sim & & rib. $\%$ & Cum.\% \\
\hline Diatoma vulgare & 4441.50 & 18.45 & & 27.38 & 27.38 \\
\hline Navicula brachysira & 2816.50 & 17.65 & & 26.19 & 53.58 \\
\hline Navicula platystoma & 1758.00 & 9.89 & & 14.68 & 68.26 \\
\hline \multicolumn{6}{|c|}{ Groups I \& II average dissimilarity $=46.53 \%$} \\
\hline Spesies & Group I Av.abund Group II Av.abund & Av.dis & Diss/SD & Contrib. \% & Cum. \% \\
\hline Diatoma vulgare & 2174.50 & 12.02 & 0.92 & 25.84 & 25.84 \\
\hline Navicula brachysira & 2816.50 & 10.30 & 2.30 & 22.13 & 47.97 \\
\hline Navicula platystoma & 1758.00 & 6.92 & 1.85 & 14.87 & 62.84 \\
\hline
\end{tabular}

Kelimpahan Chrysophyta pada media budidaya ikan nila yang diberi pakan fermentasi dengan penambahan tepung kulit ubi kayu dan probiotik dipengaruhi faktor fisika-kimia meliputi suhu, TDS, TSS, pH, DO, BOD, Nitrat, Nitrit, total fosfat.

Hasil pengukuran suhu air pada bak percobaan berkisar antara $24^{\circ} \mathrm{C}-26^{\circ} \mathrm{C}$. Suhu dalam penelitian ini baik untuk pertumbuhan Chrysophyta. Hal ini sesuai dengan pendapat Effendi (2003) bahwa Diatomae akan tumbuh dengan baik pada kisaran suhu $20^{\circ} \mathrm{C}$ $30^{\circ} \mathrm{C}$. Soedarti, et al., (2006) menambahkan bahwa temperatur yang optimum bagi produktifitas fitoplankton adalah berkisar antara $25-30^{\circ} \mathrm{C}$. Intensitas cahaya berpengaruh terhadap temperatur lingkungan maupun temperatur tubuh organisme. Penetrasi cahaya pada bak percobaan mencapai dasar bak $(120 \mathrm{~cm})$. Hasil pengukuran oksigen terlarut selama penelitian berkisar 1.893-2.81 mg/l (2.39 \pm 0.336$)$. Berdasarkan PP No 82 Tahun 2001 nilai DO untuk budidaya perikanan yang baik batas minimumnya yaitu $3 \mathrm{mg} / \mathrm{l}$. Hasil pengukuran BOD5 berkisar 3.8-5.08 mg/l (4.39mg/lı0.525).

Tabel 3. Hasil pengukuran parameter fisik-kimia pada media budidaya ikan nila yang diberi pakan fermentasi dengan penambahan tepung kulit ubi kayu dan probiotik

\begin{tabular}{|c|c|c|c|c|c|c|c|c|}
\hline \multirow{2}{*}{ No. } & \multirow{2}{*}{ Parameter } & \multirow{2}{*}{ Satuan } & \multicolumn{4}{|c|}{ Hasil Uji } & \multirow{2}{*}{ Rata-rata } & \multirow{2}{*}{ Kisaran } \\
\hline & & & A & B & $\mathrm{C}$ & $\mathrm{D}$ & & \\
\hline 1 & Suhu & ${ }^{\mathrm{o}} \mathrm{C}$ & 25 & 24 & 26 & 25 & & $24-26$ \\
\hline 2 & TDS & $\mathrm{mg} / \mathrm{l}$ & 135.50 & 121.5 & 111,00 & 98,00 & $115.10 \pm 14.12$ & $98.0-135.5$ \\
\hline 3 & TSS & $\mathrm{mg} / \mathrm{l}$ & 44.25 & 55.25 & 44.25 & 23.33 & $41.76 \pm 11.55$ & $23.33-55.25$ \\
\hline 4 & DO & mg/l & 1.89 & 2.81 & 2.33 & 2.41 & $2.39 \pm 0.33$ & $1.893-2.81$ \\
\hline 5 & BOD & $\mathrm{mg} / \mathrm{l}$ & 4.12 & 5.08 & 4.79 & 3.8 & $4.39 \pm 0.52$ & $3.80-5.08$ \\
\hline 6 & $\mathrm{pH}$ & & 6 & 7 & 7 & 6 & & 6-7 \\
\hline 7 & $\mathrm{NO}_{3} \operatorname{sbg} \mathrm{N}\left(\mathrm{NO}_{3}-\mathrm{N}\right)$ & $\mathrm{mg} / \mathrm{l}$ & 2.604 & 1.079 & 1.817 & 1.7687 & $1.73 \pm 0.56$ & $1.07-2.60$ \\
\hline 8 & $\mathrm{NO}_{2} \operatorname{sbg} \mathrm{N}\left(\mathrm{NO}_{2}-\mathrm{N}\right)$ & $\mathrm{mg} / \mathrm{l}$ & 0.194 & 0.0791 & 0.123 & 0.439 & $0.20 \pm 0.14$ & $0.12-0.43$ \\
\hline 9 & Total fosfat sbg $\mathrm{P}\left(\mathrm{PO}_{4}-\mathrm{P}\right)$ & $\mathrm{mg} / \mathrm{l}$ & 0.976 & 0.931 & 0.845 & 0.976 & $0.92 \pm 0.05$ & 0.84-0.97 \\
\hline
\end{tabular}

Hasil pengukuran $\mathrm{pH}$ di bak budidaya berkisar antara 6-7. Maka besarnya pH yang diperoleh selama penelitian masih memenuhi untuk kehidupan Chrysophyta. Prescott (1973) dalam Sitorus (2009), mengatakan bahwa batas toleransi organisme terhadap $\mathrm{pH}$ bervariasi tergantung pada faktor fisika, kimia dan biologi. Derajat keasaman $(\mathrm{pH})$ yang ideal untuk kehidupan fitoplankton berkisar antara 6,5-8,0. Keanekaragaman fitoplankton akan mengalami penurunan yang cukup besar pada kisaran pH 5,0 5,5. Bahkan pada $\mathrm{pH}<4$ sebagian besar fitoplankton akan mati akan tidak mampu mentolerir $\mathrm{pH}$ yang kecil. Nilai $\mathrm{pH}$ berpengaruh terhadap komposisi jenis yang terdapat di perairan tersebut. Pada saat terjadi blooming algae, $\mathrm{pH}$ perairan dapat mencapai 10 (Sylvester, et al., 2002).

Hasil pengukuran nitrat di bak budidaya berkisar antara 1,079-2,604 mg/l (1,736mg/lı0,569). Hal ini menunjukkan bahwa kadar nitrat di bak percobaan masih dalam keadaan normal. Menurut Notestein, et al., (2003), kadar nitrat di perairan berkisar 0,1 sampai $5 \mathrm{mg} / \mathrm{l}$, sedangkan di perairan tercemar berat kadar nitrat bisa mencapai $100 \mathrm{mg} / \mathrm{l}$.

Hasil pengukuran nitrit di bak budidaya berkisar antara 0,123-0,439 mg/l (0,201 mg/l $\pm 0,140)$. Nilainya masih terlalu tinggi dari aturan berdasarkan PP No.82 Tahun 2001 nilai NO2 untuk budidaya perikanan yang baik batas maksimumnya yaitu 0,06 mg/l. 
Tingginya kadar nitrit dapat terjadi karena terdapat bahan organik dalam air berupa kandungan tepung kulit ubi kayu dari sisa pakan yang mengendap didasar bak percobaan. Menurut Hendrawati et al., (2006) meningkatnya kadar nitrit berkaitan erat dengan bahan organik. Kadar nitrit dalam air pada penelitian ini tidak baik untuk kehidupan organisme akuatik.

Hasil pengukuran fosfat total selama penelitian berkisar $0.845 \mathrm{mg} / \mathrm{l}-0.976 \mathrm{mg} / \mathrm{l}(0.92 \mathrm{mg} / \mathrm{l} \pm 0.059)$. Berdasarkan PP No.82 Tahun 2001 nilai fosfat total untuk budidaya perikanan yang baik batas maksimumnya yaitu $1 \mathrm{mg} / \mathrm{l}$. Keberadaan fosfat di perairan adalah sangat penting terutama berfungsi dalam pembentukan protein dan metabolisme bagi organisme.

Hasil pengukuran TDS selama penelitian berkisar antara $98 \mathrm{mg} / \mathrm{l}$ - 135,5 mg/l (115.1mg/lı14.12). Hasil pengukuran TDS selama penelitian pada tiap perlakuan masih mendukung kehidupan organisme berdasarkan PP No.82 Tahun 2001 bagi baku mutu kelas III, besarnya residu tersuspensi suatu perairan untuk pembudidayaan ikan air tawar, peternakan dan air untuk mengairi pertanaman tidak boleh lebih dari $1000 \mathrm{mg} / \mathrm{l}$ (KLH, 2002). Padatan terlarut total (Total Dissolved Solid atau TDS) adalah bahan-bahan terlarut dan koloid yang berupa senyawa-senyawa kimia dan bahan-bahan lain, yang tidak tersaring pada kertas saring berdiameter $0,45 \mu \mathrm{m}$.

Hasil pengukuran TSS selama penelitian berkisar antara $23.33 \mathrm{mg} / \mathrm{l}-55.25 \mathrm{mg} / \mathrm{l}$ (41.766 mg/lı11.55). Menurut PP No.82 Tahun 2001 bagi baku mutu kelas III, besarnya residu terlarut suatu perairan untuk pembudidayaan ikan air tawar, peternakan dan air untuk mengairi pertanaman tidak boleh lebih dari 400 mg/l (KLH, 2002). Residu dianggap sebagai ketersediaan total bahan terlarut dan tersuspensi dalam air. Total Suspended Solid atau TSS terdiri atas lumpur dan pasir halus serta jasad-jasad renik, terutama disebabkan oleh kikisan tanah atau erosi tanah yang terbawa ke badan air (Effendi, 2003).

\section{KE SIMPULAN DAN SARAN}

Berdasarkan hasil dan pembahasan yang telah dilakukan maka dapat diambil kesimpulan bahwa; Kekayaan spesies pada media budidaya ikan nila yang diberi pakan fermentasi dengan penambahan tepung kulit ubi kayu dan probiotik adalah 20 spesies terdiri dari klas Bacillariophyceae dengan kisaran 8-13 spesies, dan kelimpahan pada media budidaya ikan nila yang diberi pakan fermentasi dengan penambahan tepung kulit ubi kayu dan probiotik berkisar 5160-13292 ind/l. Analisis cluster menunjukkan bahwa kelimpahan Chrysophyta antar perlakuan mempunyai tingkat kesamaan cukup tinggi (>50\%) yaitu berkisar antara 65,58\%-79,80\%.
Kontribusi spesies yang memberikan nilai similaritas dan disimilaritas paling tinggi yaitu Diatoma vulgare, Navicula brachysira dan Navicula platystoma.

Saran yang diajukan yaitu penggunaan pakan fermentasi dengan penambahan tepung kulit ubikayu dan probiotik menghasilkan kelimpahan Chrysophyta yang tinggi sehingga pakan fermentasi dengan penambahan tepung kulit ubikayu dan probiotik dapat digunakan sebagai bahan alternatif pupuk.

\section{DAFTAR PUSTAKA}

American Public Health Association (APHA). 1985. Standard methods for the examination of water and waste water. New York: APHA Inc.

Dodds WK. 2002. Freshwater ecology: concepts and environmental aplications. San Diego: Academic Press.

Effendi. 2003. Telaah kualitas air bagi pengelolaan sumberdaya dan lingkungan perairan. Jogjakarta: Kanisius.

Hendrawati, Prihati TH, Rohmah NN. 2006. Analisis kadar phosphat dan n-nitrogen (amonia, nitrat, nitrit) pada tambak air payau akibat rembesan lumpur Lapindo di Sidoarjo, Jawa Timur. Jurnal valensi. 1(3): 133-141.

Kementerian Lingkungan Hidup (KLH). 2002. Himpunan Peraturan dan Perundang- undangan di Bidang Pengelolaan Lingkungan Hidup dan Pengendalian Lingkungan, Era Otada.

Makatipu PC, Peristiwady T, Leuna M. 2010. Biodiversitas ikan target di terumbu karang taman nasional Bunaken, Sulawesi Utara. Oseanologi dan Limnologi di Indonesia. 36(3): 309-328.

Muhidin NH, Juli N, Aryantha INP. 2001. Peningkatan kandungan protein kulit umbi ubi kayu melalui proses fermentasi. JMS. 6(1): 1-12.

Notestein SK, Frazer TK, Hoyer MV, Canfield DE. 2003. Nutrient limitation of periphyton in a spring-fed, coastal stream in Florida, USA. J. Aquat. Plant Manage. 41:57-60.

Odum EP. 1993. Dasar-dasar ekologi [diterjemahkan oleh Samingan T, Srigandono B. Yogyakarta: Gajahmada University Press.

Peraturan Pemerintah Republik Indonesia no. 82. 2001. Pengelolaan Kualitas Air dan Pengendalian Pencemaran Air. Jakarta: Himpunan Peraturan di Bidang Pengendalian Dampak Lingkungan.

Rukmana R.1997. Ubi kayu budi daya dan pascapanen. Yogyakarta: Kanisius.

Sachlan M. 1982. Planktonologi. Correspondence Course Centre. Jakarta: Direktorat Jenderal Perikanan.

Shirota A. 1966. The plankton of south vietnam. Tokyo: Technical Cooperation.

Sitorus M. 2009. Hubungan nilai produktivitas primer dengan konsentrasi klorofil a dan faktor fisik kimia di perairan Danau Toba, Balige, Sumatera Utara. Medan: Sekolah PascasarjanaUniversitas Sumatera Utara.

Soedarti T, Aristiana J, Soegianto A. 2006. Diversitas fitoplankton pada ekosistem perairan Waduk Sutami, Malang. Universitas Airlangga-Surabaya. Berk. Penel. Hayati. 2006: 97-103.

Sylvester BD, Nelvy, Sudhiharna. 2002. Budidaya fitoplankton dan zooplankton. Lampung: BBL.

Sze P. 1993. A biology of the algae. London: WMC Brown Publishers.

Thompson RH. 1966. Algae. In: Edmonson WT. Freshwater biology. 2nd ed. Seattle: University of Washington. p 115-170.

Wehr JD, Sheath RG. 2003. Freshwater algae of North America: ecology and classification. New York: Academic Press.

Widyastuti E, Sukanto, Rukayah S. 2010. Penggunaan pakan fermentasi pada budidaya ikan sistem keramba jaring apung untuk mengurangi eutrofikasi di Waduk Wadaslintang. Limnotek. 17(2): 191-200.

Whitton BA. 1975. River ecology. London: Blackwell Scientific Publication. 